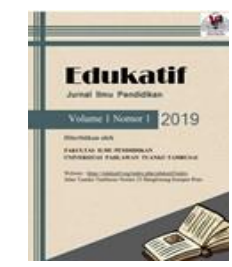

\title{
PENGARUH PEMBELAJARAN KOOPERATIF TIPE GI TERHADAP PENINGKATAN KEMAMPUAN KONEKSI MATEMATIK SISWA SEKOLAH DASAR
}

\author{
Fadhilaturrahmi $^{1}$
}

Universitas Pahlawan Tuanku Tambusaii ${ }^{1}$

e-mail : fadhilaturrahmi.pgsd@gmail.com

\begin{abstract}
Abstrak
Penelitian ini bertujuan untuk melihat pengaruh pembelajaran kooperatif tipe GI terhadap peningkatan kemampuan koneksi matematik siswa sekolah dasar. Penelitian ini merupakan penelitian kuasi eksperimen, dengan desain yang digunakan adalah "pretest-posttest two treatman design". Populasi sekaligus sebagai sampel dalam penelitian ini adalah seluruh siswa kelas V Sekolah dasar di sekolah dasar Ibnu Sina kabupaten Bandung. Instrumen yang digunakan dalam pengumpulan data adalah tes koneksi matematik bentuk uraian. Hasil penelitian menunjukkan bahwa pembelajaran matematika tipe GI sama-sama memiliki pengaruh dalam peningkatan kemampuan koneksi matematik siswa sekolah dasar. Maka pembelajaran matematika dengan pembelajaran kooperatif tipe GI dapat dijadikan sebagai salah satu pembelajaran yang dapat diterapkan dalam upaya meningkatkan kemampuan siswa khususnya kemampuan koneksi matematik siswa sekolah dasar.

Kata kunci: Kemampuan Koneksi Matematik, Pembelajaran Kooperatif Tipe GI.
\end{abstract}

@Edukasi: Jurnal Ilmu Pendidikan FIP UPTT 2019

\begin{tabular}{ll}
\hline$\square$ Corresponding author : & \\
Address : & ISSN xxxx-xxxx (Media Cetak) \\
Email : fadhilaturrahmi.pgsd@gmail.com & ISSN xxxx-xxxx(Media Online) \\
Phone : - &
\end{tabular}




\section{PENDAHULUAN}

The National Council of Teachers of Mathematics (Yuniawatika, 2011:6) menetapkan bahwa terdapat 5 kemampuan yang perlu dimiliki siswa melalui pembelajaran matematika yang tercakup dalam standar proses yaitu (1) pemecahan masalah (problem solving), (2) penalaran dan pembuktian (reasoning and proof), (3) koneksi (communication), (4) koneksi (connection) dan (5) representasi (representation). Dari lima kemampuan di atas, pengembangan kemampuan koneksi menjadi salah satu fokus perhatian dalam penelitian ini. Kemampuan koneksi matematis diperlukan sejak dini melalui pembelajaran di kelas agar siswa bisa memecahkan masalah dan mengaplikasikan konsep matematika sebagai bekal hidup siswa masa sekarang dan masa yang akan datang. NCTM (2000: 64) menyatakan "when student can connect mathematical ideas, their understanding is deeper and more lasting". Apabila para siswa dapat menghubungkan gagasan-gagasan matematis, maka pemahaman mereka akan lebih mendalam dan lebih bertahan lama. Pemahaman siswa akan lebih mendalam jika siswa

dapat mengaitkan antar konsep yang telah diketahui siswa dengan konsep baru yang akan dipelajari oleh siswa. Seseorang akan lebih mudah mempelajari sesuatu bila belajar didasari kepada apa yang telah diketahui orang tersebut. Bruner (Ruseffendi, 2006) juga mengungkapkan bahwa agar siswa lebih berhasil dalam belajar matematika, siswa harus lebih banyak diberi kesempatan untuk melihat kaitan-kaitan, baik kaitan antara dalil dan dalil, topik dan topik maupun antara cabang matematika. Hasil observasi di lapangan terkait kemampuan koneksi ini sebenarnya sudah ada pada siswa, namun belum berkembang dengan baik. Hal ini terlihat saat siswa belum bisa membuat koneksi antara satu konsep matematika yang ia pelajari hari itu dengan konsep matematika yang telah ia pelajari sebelumnya termasuk membuat koneksi dengan kehidupan sehari-hari/dunia nyata. Berdasarkan pada penjabaran di atas, tentang pentingnya mengembangkan kemampuan koneksi matematik dan melihat pada kesenjangan di lapangan, maka jika kemampuan ini tidak dikembangkan dengan baik, maka tujuan pembelajaran matematika secara tidak langsung juga tidak akan tercapai. Hal ini, akan membawa dampak negatif terhadap pengaplikasian kemampuan matematika tersebut menjadi terhambat pada siswa ketika menyelesaikan permasalahanpermasalahan matematika yang menggunakan kemampuan tersebut dalam pemecahannya..

Pembelajaran kooperatif tipe GI adalah rencana pengorganisasian ruang kelas dimana siswa bekerja dalam kelompokkelompok kecil dengan menggunakan investigasi kooperatif, diskusi kelompok, serta perencanaan dan proyek kooperatif. Selanjutnya Slavin (Samosir, 1995:114) menjelaskan bahwa langkah-langkah pembelajaran kooperatif GI adalah sebagai berikut : (1) mengidentifikasi topik dan pengorganisasian siswa dalam kelompokkelompok, (2) merencanakan tugas belajar, (3) melaksanakan penelitian, (4) menyiapkan sebuah laporan akhir, (5) menyajikan laporan akhir dan (6) evaluasi. Selain dari pembelajaran kooperatif tipe GI ini peneliti juga ingin mengetahui pengaruh pembelajaran kooperatif tipe KONVENSIONAL terhadap kemampuan matematis ini. Pembelajaran kooperatif tipe KONVENSIONAL adalah pembelajaran kooperatif yang menempatkan siswa ke dalam tim-tim belajar yang beranggotakan empat sampai lima orang yang bercampur tingkat kinerja. Guru menyajikan pelajaran dan kemudian siswa bekerja dalam tim mereka memastikan semua anggota tim telah menguasai pelajaran tersebut. Akhirnya, semua siswa mengikuti ujian-ujian kecil sendiri-sendiri tentang bahan tersebut dan pada saat itu mereka tidak boleh membantu satu sama lain. 


\section{METODE PENELITIAN}

Desain eksprimen yang akan digunakan dalam penelitian ini adalah design dari Cohen (2008:278) yaitu the pretest-postest two treatman design. Pola rancangan digambarkan sebagai

berikut:

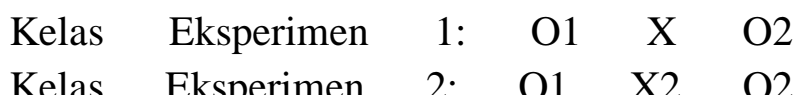

$\begin{array}{lllll}\text { Kelas Eksperimen } & 2: & \mathrm{O} 1 & \mathrm{X} 2 & \mathrm{O} 2\end{array}$ Keterangan

$\mathrm{O} 1$

\section{Nilai}

pretes

$\mathrm{O} 2$

Nilai

post-tes

$\mathrm{X} 1$ : Pembelajaran

konvensional

$\mathrm{X} 2$ : Pembelajaran dengan GI

Subjek dalam penelitian ini adalah semua siswa kelas V SD Islam Ibnu Sina yang terdiri dari dua kelas yaitu kelas VA (Kelas Ahmad Dahlan) dan kelas VB (Kelas Buya Hamka). Kelas VA yang terdiri dari 18 orang siswa dan kelas VB yang terdiri dari 18 orang siswa. Pada Kelas VA, diberikan perlakuan pembelajaran konvensional, sedangkan di kelas VB diberi perlakuan pembelajaran kooperatif tipe GI.

\section{HASIL PENELITIAN DAN PEMBAHASAN}

Bersumber dari data-data penelitian terutama membandingkan skor pretes dan postesnya secara keseluruan siswa, dimana terlihat bahwa pada saat pretes kemampuan siswa berada pada kategori rendah, setelah diberi tindakan dengan pembelajaran kooperatif tipe konvensional, lalu dilakukan postes kemampuan siswa meningkat menjadi kategori sedang. Begitupun pada pembelajaran kooperatif tipe GI, rata-rata pretes menunjukkan kemampuan siswa berada pada kategori sedang, setelah diberikan pembelajaran kooperatif tipe GI, maka rata-rata postes siswa menunjukkan kemampuan pada kategori sedang yang hampir mendekati kategori tinggi. Hal ini menjadi gambaran bahwa pembelajaran kooperatif tipe konvensional dan GI berpengaruh karena dapat meningkatkan kemampuan koneksi siswa. Pada kedua pembelajaran terutama saat siswa menjawab pertanyaan yang ada di LAS atau lembar investigasi beberapa pertanyaan diarahkan untuk meminta siswa membuat hubungan /koneksi antara matematika dan dengan kehidupan nyata. Hal ini dilakukan agar siswa lebih paham dan lebih mendalam dalam memaknai konsep yang akan dipelajari karena dengan meminta siswa melakukan pengkoneksian baik yang dilakukan dalam pembelajaran kooperatif tipe konvensional ataupun GI akan bisa melatih "working memory" siswa yang di dalam psikologi merupakan "meja kerja" untuk pemprosesan infomasi, dimana akan memindahkan informasi ke ingatan sensorik (ingatan jangka panjang) siswa.

Jika dilihat dari hasil uji statistik yang telah dilakukan, diperoleh kesimpulan bahwa kemampuan koneksi kelompok tinggi yang belajar belajar dengan pembelajaran kooperatif tipe GI tidak lebih baik dibandingkan kemampuan koneksi kelompok tinggi yang belajar dengan pembelajaran kooperatif tipe konvensional.

Hal yang sama juga ditemukan pada kemampuan koneksi kelompok rendah, dimana kemampuan koneksi kelompok rendah yang belajar dengan pembelajaran kooperatif tipe GI juga tidak lebih baik daripada kemampuan koneksi kelompok rendah yang belajar dengan pembelajaran kooperatif tipe konvensional Artinya, pengaruh dari kedua pembelajaran baik pembelajaran kooperatif tipe konvensional maupun tipe GI, memiliki pengaruh yang sama untuk siswa berkemampuan tinggi dan rendah. Temuan di atas menjadi gambaran bahwa adanya pengaruh dari pembelajaran kooperatif tipe konvensional dan GI terhadap kemampuan koneksi pada siswa berkemampuan tinggi dan rendah. Dilihat dari proses pembelajarannnya dimana pembelajaran kooperatif baik konvenional maupun GI memberikan ruang bagi siswa untuk menyeimbangkan proses kognitifnya saat langkah diskusi berlangsung. Bagi siswa yang memiliki konsep yang sudah benar akan melakukan proses asimilasi dalam proses kognitifnya, sedangkan bagi siswa yang yang memiliki konsep yang salah dalam kognitifnya bisa melakukan proses akomodasi agar memperoleh keseimbangan kognitif. Jika dibandingkan kualitas peningkatannya, dari hasil uji statistik yang telah dipaparkan disimpulkan bahwa kedua pembelajaran sama kualitasnya dalam peningkatan kemampuan koneksi siswa. Untuk siswa berkemampuan sedang terlihat dari $\mathrm{n}$ gainnya bahwa untuk pembelajaran kooperatif tipe GI dan konvensional sama-sama berada pada kategori sedang. 
Setelah dilakukan uji statistik diperoleh temuan bahwa kemampuan koneksi matematik kelompok sedang pada pembelajaran GI lebih baik daripada kemampuan koneksi kelompok sedang pada pembelajaran konvensional Hal ini dapat terjadi, berdasarkan analisis peneliti selain dari proses kognitif yang dialami oleh setiap siswa pada berbagai kategori kemampuan termasuk siswa berkemampuan sedang, hal ni juga didasarkan pada langkah proses pembelajaran GI yang memberikan ruang lebih banyak untuk siswa untuk menyeimbangkan proses kognitifnya, baik melalui bertanya pada teman ataupun pada guru agar proses asimilasi dan akomodasi yang difasilitasi oleh langkah pembelajaran GI

\section{KESIMPULAN}

Berdasarkan hasil penelitian yang telah dikemukakan pada bab sebelumnya, maka diperoleh kesimpulan sebagai berikut :

1. Terdapat perbedaan peningkatan kemampuan koneksi antara siswa yang belajar dengan pembelajaran kooperatif tipe konvensional dengan siswa yang belajar dengan pembelajaran kooperatif tipe GI

2. Kemampuan koneksi matematis kelompok tinggi dengan pembelajaran kooperatif tipe GI tidak lebih baik dari kemampuan koneksi matematis kelompok tinggi dengan pembelajaran kooperatif Tipe konvensional

3. Kemampuan koneksi matematis kelompok sedang dengan pembelajaran kooperatif tipe GI lebih baik dari kemampuan koneksi matematis kelompok sedang dengan pembelajaran kooperatif Tipe konvensional.

4. Kemampuan koneksi matematis kelompok rendah dengan pembelajaran kooperatif

tipe GI tidak lebih baik dari kemampuan koneksi katematis kelompok rendah dengan pembelajaran kooperatif Tipe konvensional

\section{DAFTAR PUSTAKA}

Lestari, P. (2009). Peningkatan Kemampuan Pemahaman dan Koneksi Matematis Siswa SMK Melalui Pendekatan Pembelajaran Kontekstual. Tesis SPS UPI Bandung : Tidak diterbitkan

National Council of Teachers of Mathematics. (2000). Principles and Standars for School Mathematics. Reston VA : The National Council of Teachers of Matematics Inc.

Ruseffendi, E.T. (2006). Pengantar Kepada Membantu Guru Mengembangkan Kompetensinya Dalam Pengajaran Matematika untuk meningkatkan CBSA. Bandung : Tarsito

Samosir, M.(2011). Psikologi Pendidikan Teori dan Praktik. Jakarta: Indeks

Yuniawatika. (2011). Penerapan Pembelajaran Matematika Dengan Strategi REACT Untuk Meningkatkan Kemampuan Koneksi dan Representasi Matematika Siswa Sekolah Dasar. Tesis Magister pada SPs UPI Bandung: tidak diterbitkan 